\title{
Effects of dietary betaine supplementation subjected to heat stress on milk performances and physiology indices in dairy cow
}

\author{
L. Zhang', S.J. Ying', W.J. An ${ }^{1}$, H. Lian ${ }^{1}$, G.B. Zhou ${ }^{1}$ and Z.Y. Han ${ }^{1}$ \\ ${ }^{1}$ Institute of Dairy Science, College of Animal Science and Technology, \\ Nanjing Agricultural University, Nanjing, China \\ ${ }^{2}$ Institute of Animal Science, Jiangsu Academy of Agricultural Sciences, \\ Jiangsu, China \\ Corresponding author: Z.Y. Han \\ E-mail: zyhan6708@njau.edu.cn
}

Genet. Mol. Res. 13 (3): 7577-7586 (2014)

Received May 28, 2013

Accepted July 27, 2014

Published September 12, 2014

DOI http://dx.doi.org/10.4238/2014.September.12.25

\begin{abstract}
This study aimed to determine whether feeding betaine to cows elevates their production performance during summer heat stress. Thirty-two lactating Holstein cows were randomly divided into 4 groups: the control group, which received a total mixed ration (TMR), and 3 experimental groups that received TMR blended with $10 \mathrm{~g} /$ day (group I), $15 \mathrm{~g} /$ day (group II), and $20 \mathrm{~g} /$ day (group III) betaine for 8 weeks. Milk and blood were sampled throughout the experimental period. The average maximum and minimum air temperatures were 28.3 and $24.1^{\circ} \mathrm{C}$, respectively. The average temperature-humidity index was 78.6 units. The results showed that feeding betaine to cows increased feed intake, milk yield, milk lactose, milk protein, plasma cortisol, glutathione peroxidase, superoxide dismutase, and malondialdehyde levels $(\mathrm{P}<0.05)$; however, it caused HSP70 levels to decrease $(\mathrm{P}<0.05)$. The milk performance of group II was significantly affected. These results indicate that supplementing betaine to the diet of dairy cows increases
\end{abstract}


their milk performance and improves their antioxidant capacity; these processes help relieve the cow from heat stress. In conclusion, supplementing dairy cows with $15 \mathrm{~g}$ /day betaine generated the most positive influence on performance and productivity, and hence caused the greatest reduction in heat stress.

Key words: Dairy cow; Heat stress; Betaine

\section{INTRODUCTION}

Dairy cows exposed to high ambient temperatures and high relative humidity during summer are not able to dissipate sufficient body heat to prevent a rise in body temperature. In general, existing studies suggest that the optimal environmental temperatures for cattle range from 5 to $25^{\circ} \mathrm{C}$. A temperature-humidity index (THI) above 72 units usually causes a reduction in dry matter intake (DMI) and milk production in lactating dairy cows (Armstrong, 1994). Consequently, high ambient temperatures and high relative humidity during summer cause a decline in milk yield and DM intake by dairy cows (Armstrong, 1994; Huber et al., 1994). Lactation and environmental conditions (i.e., mainly seasonal variation in air temperature) are considered to act as physiological stressors on animals, affecting their biological systems (Al-Saiady et al., 2004). Heat dissipation is the transfer of body heat from the body core to the surface and then to the environment. Increased levels of heat dissipation arise via enhanced peripheral vasomotor function and evaporative heat loss. This phenomenon might serve to alleviate some of the reductions in DMI and, thus, increase milk production (Zimbelman et al., 2010).

Methionine (Met) is frequently one of the most limiting amino acids in dairy rations, with its metabolism being closely associated to that of betaine (Davidson et al., 2008). Betaine is also termed betaine anhydrous or trimethylglycine (TMG), and provides methyl (which eventually forms Met) in the formation of homocysteine. Within this framework, Davidson et al. (2008) demonstrated the metabolic relationships of these various substances; specifically, the dietary supply of either choline or betaine affects Met requirements, with Met supply subsequently affecting betaine and choline metabolism.

Heat stress potentially leads to a decline in milk production, in addition to reducing the health of dairy cows. Therefore, most existing research has focused on overcoming this limitation. This study aimed to determine the effect of betaine supplementation on the lactation performance and blood parameters of lactating dairy cows exposed to hot, humid weather conditions. The assimilated information was used to identify the ideal dose of betaine supplementation to counteract the effects of heat stress. Through this study, we hope to provide a new reference towards relieving heat stress in dairy cows.

\section{MATERIAL AND METHODS}

\section{Animals and diets}

The experiment was conducted from July to September 2012. Thirty-two Holstein 
cows from a commercial dairy farm in Nanjing Province, China, were selected. These cattle produced $33.78 \pm 0.06 \mathrm{~kg}$ of milk/day and were balanced for parity (first and second lactation) and stage of lactation $(101 \pm 0.11$ days in milk). These cattle were brought into the tie-stalls for milking and feeding. Animals were randomly assigned to 1 of 4 treatment groups ( 8 cows per group); specifically, the control group had no betaine added (C), group I received $10 \mathrm{~g} / \mathrm{d}$ betaine, group II received $15 \mathrm{~g}$ /day betaine, and group III received $20 \mathrm{~g}$ /day betaine with their fodder. The animals were fed a standard diet for 7 days before the beginning of the experiment. The cow weight at the start and end of the experiment was recorded. All records of body weight were documented by the same investigator throughout the study.

During the experiment, the animals were fed TMR (total mixed ration) 3 times daily at 7:30 am, 2:30 pm, and 9:30 pm. The TMR primarily contained corn silage, alfalfa hay, and corn grain balanced to meet or exceed nutrient requirements (Table 1), based on the NRC (National Research Council) standards (NRC, 2001). The cows were given access to clean water ad libitum. Cow health was monitored daily by dairy personnel and weekly by the experimentalist.

\begin{tabular}{lclc}
\multicolumn{4}{l}{ Table 1. Ingredient composition of dietary treatments (\% of dry matter). } \\
\hline Ingredients & Percentage (\%) & Nutrient composition calculated & Content $(\%)$ \\
\hline Corn grain & 14.99 & ME $(\mathrm{Mkcal} / \mathrm{kg})$ & 2.38 \\
Steam-flaked corn & 9.33 & Crude protein & 16.9 \\
Distillers dried grain with solubles & 10.29 & NDF $(\%)$ & 39.32 \\
Soybean meal & 4.87 & ADF $\%)$ & 26.12 \\
Calcium hydrogen phosphate & 0.45 & Calcium & 0.80 \\
Salt & 0.24 & Phosphorus & 0.47 \\
Limestone & 0.36 & & \\
Sodium bicarbonate & 0.60 & & \\
Cotton seed & 4.16 & & \\
Brewer's spent grain & 4.12 & & \\
Corn silage & 13.22 & & \\
Oat hay & 10.07 & & \\
Alfalfa hay & 17.00 & & \\
Mineral-vitamin premix & & & \\
Dry apple pomace & 3.71 & & \\
\hline
\end{tabular}

aProvided per kg of premix: VA 1500 kIU,VD3 300 kIU,VE $1800 \mathrm{kIU}$, nicotinic acid $2500 \mathrm{mg}, \mathrm{Cu} 1500 \mathrm{mg}$, Fe 5600 mg, Mn 4500 mg, Zn 9600 mg, I 150 mg, Se 40 mg, Co 60 mg. ME = metabolizable energy; NDF $=$ neutral detergent fiber; $\mathrm{ADF}=$ acid detergent fiber.

\section{Ambient conditions}

Ambient temperature and relative humidity $(\mathrm{RH})$ were recorded at a height of 1.5 $\mathrm{m}$ above the floor in the cowshed. Maximum and minimum ambient temperatures were recorded daily, and THI was calculated according to the equation THI $=0.72\left(\mathrm{~T}_{\mathrm{db}}+\mathrm{T}_{\mathrm{wb}}\right)+$ 40.6, where $\mathrm{T}_{\mathrm{db}}$ is the temperature of the dry bulb and $\mathrm{T}_{\mathrm{wb}}$ is the temperature of the wet bulb (Maust et al., 1972). Temperature of dry bulbs means actual ambient temperature, while temperature of wet bulbs means sendible temperature. For each $24-\mathrm{h}$ period, the maximum THI was calculated from the maximum temperature. The minimum RH and the minimum THI were calculated using the minimum temperature and the maximum RH (West, 2003; West et al., 2003). The environmental temperature and THI averaged $28.31^{\circ} \mathrm{C}$ and 78.68 , respectively. 


\section{Thermal status measurements}

Rectal temperature was obtained using a Fang Da rectal thermometer (Fang Da Instruments Co., Ltd., Shanghai, China), and was recorded 3 times a day at 8:00 am, 3:00 pm, and 10:00 pm. The manufacturer reports a measurable range of $35^{\circ}$ to $43^{\circ} \mathrm{C}$, with an accuracy of \pm $0.2^{\circ} \mathrm{C}$. Temperatures were recorded at 1 -min intervals over the 7 -day period. Respiration rates (RR) were obtained 3 times per day $(8: 00 \mathrm{am}, 3: 00 \mathrm{pm}$, and 10:00 pm) by visually counting flank movement during a $1 \mathrm{~min}$ period. The pulse rate was determined from the tail vein 3 times per day (8:00 am, 3:00 pm, and 10:00 pm) over a 1 min interval.

\section{Milk sampling and analyses}

Cows were milked 3 times a day, and daily milk yields from 2 of the milkings were recorded every week. Milk samples from 3 consecutive milking were collected from 8 cows in each group, and were composited once weekly from consecutive 8:00 am, 3:00 pm, and 9:00 pm milkings, and then frozen at $-20^{\circ} \mathrm{C}$ until analysis. Milk samples were analyzed for milk fat, milk protein, and milk lactose by an automatic milk composition analyzer (DELTA LactoScope FTIR, Holland).

\section{Blood sampling and analyses}

Blood samples were collected from the coccygeal venipuncture of each animal from all groups. Blood samples were drawn from the tail vein into EDTA tubes on the last day of the experimental period. After collection, all samples were immediately placed on ice for transport to the laboratory. The EDTA-containing samples were centrifuged for $15 \mathrm{~min}$ at $2500 \mathrm{~g}$ at $4^{\circ} \mathrm{C}$, and the plasma was harvested and stored at $-20^{\circ} \mathrm{C}$ until analysis.

Cholesterol, glucose, blood urea oat hay nitrogen, oat hay triglycerides, lactate dehydrogenase, creatine kinase, and glutamic-pyruvic transaminase were determined using an automatic biochemical analyzer (AU5800, BECKMAN coulter, USA). Glutathione peroxidase (GSH-Px), total antioxidant capacity (T-AOC), malondialdehyde (MDA), and superoxide dismutase (SOD) were assayed using a commercial kit (Jiancheng Co., Ltd., Nanjing, China). Triiodothyronine $\left(\mathrm{T}_{3}\right)$, tetraiodothyronine $\left(\mathrm{T}_{4}\right)$, and cortisol (CORT) were determined by radioimmunoassay.

\section{Statistical analysis}

Statistical analyses were performed using the SPSS statistical software program (version 13.0). The data are reported as means $\pm \mathrm{SE}$, and differences were regarded as significant at $\mathrm{P}<0.05$. We first determined whether the distribution of all data followed a normal distribution using the Kolmogorov-Smirnov goodness-of-fit test. Where data were not normally distributed, they were transformed to logarithms, re-tested for normality before analysis, and, if still not normalized, the data were tested using the equivalent nonparametric test. For the analysis of repeated measurements, the liner mixed model of SPSS was used with comparisons using the Bonferroni correction. The model included the fixed effects of treatment and day and their interaction. Data with repeated measurements included: milk yield, milk lactose, 
milk protein, milk fat, rectal temperature, respiration rate, and pulse rate. The other data were analyzed for treatment effect by one-way ANOVA. Post hoc differences between treatment groups were further examined by the Duncan test.

\section{RESULTS}

\section{Ambient air temperature}

The weather conditions during the experimental period (July to September) were typically very hot and humid. The average of the maximum and minimum ambient air temperature during the experimental period was $28.3^{\circ} \pm 1.75^{\circ} \mathrm{C}$ and $24.11^{\circ} \pm 0.41^{\circ} \mathrm{C}$, respectively. The calculated THI averaged 78.66 units.

\section{Rectal temperature, respiration rate, and pulse rate}

Dietary betaine supplementation did not affect the body weight, rectal temperature, respiration rate, or pulse rate of dairy cows $(\mathrm{P}>0.05)$ (Table 2$)$.

Table 2. Effects of betaine on rectal temperature, respiration rate, and pulse of dairy cows under heat stress.

\begin{tabular}{lrcccc}
\hline Item & Time & C & I & II & III \\
\hline Rectal temperature $\left({ }^{\circ} \mathrm{C}\right)$ & $8: 00 \mathrm{am}$ & $38.39 \pm 0.16$ & $38.43 \pm 0.15$ & $38.38 \pm 0.13$ & $38.50 \pm 0.13$ \\
& $3: 00 \mathrm{pm}$ & $38.83 \pm 0.23$ & $38.81 \pm 0.21$ & $38.78 \pm 0.19$ & $38.79 \pm 0.18$ \\
& $10: 00 \mathrm{pm}$ & $38.73 \pm 0.18$ & $38.70 \pm 0.15$ & $38.71 \pm 0.133$ & $38.66 \pm 0.11$ \\
Respiration rate (breaths/min) & $8: 00 \mathrm{am}$ & $56.94 \pm 1.89$ & $56.98 \pm 1.86$ & $56.79 \pm 1.94$ & $56.90 \pm 1.97$ \\
& $3: 00 \mathrm{pm}$ & $67.08 \pm 2.20$ & $67.09 \pm 2.15$ & $67.04 \pm 2.06$ & $67.06 \pm 1.98$ \\
& $10: 00 \mathrm{pm}$ & $55.79 \pm 1.22$ & $55.61 \pm 1.47$ & $55.56 \pm 1.49$ & $55.67 \pm 1.47$ \\
Pulse (times/min) & $8: 00 \mathrm{am}$ & $70.76 \pm 1.31$ & $70.86 \pm 1.68$ & $70.59 \pm 1.15$ & $70.82 \pm 1.71$ \\
& $3: 00 \mathrm{pm}$ & $73.60 \pm 1.77$ & $73.52 \pm 2.08$ & $73.36 \pm 1.88$ & $73.43 \pm 1.77$ \\
& $10: 00 \mathrm{pm}$ & $71.64 \pm 1.33$ & $71.68 \pm 1.35$ & $71.61 \pm 1.60$ & $71.62 \pm 1.533$ \\
\hline
\end{tabular}

$\mathrm{C}=$ control group $(0 \mathrm{~g} /$ day of betaine $)$; I = group I ( $10 \mathrm{~g} /$ day of betaine $)$; II = group II ( $15 \mathrm{~g} /$ day of betaine $)$; III = group III ( $20 \mathrm{~g}$ /day of betaine).

\section{Lactation performance}

Milk yield and milk composition from cows are shown in Table 3 and Figure 1. Dietary betaine supplementation elevated the milk yield, milk protein, and milk lactose levels during experiment period (Figure 1) $(\mathrm{P}<0.05)$. Milk yield was higher in experimental groups II and III $(\mathrm{P}<0.05)$ compared to the control group and group I. Milk yield in groups II and III increased by 5.27 and $4.22 \%$, respectively, compared to the control. However, the percentage of milk lactose was higher in group II $(\mathrm{P}<0.05)$ compared to the control and group III. In addition, the percentage of milk lactose in groups I and III was also higher (P $<0.05)$ compared to the control. The percentage milk lactose in groups I, II, and III was higher by $2.00,2.99$, and $1.40 \%$, respectively, compared to the control. However, betaine did not affect milk fat. The percentage of milk protein was higher $(\mathrm{P}<0.05)$ in groups II and III compared to the control. 
Table 3. Effects of betaine on lactation performance of dairy cows during summer heat stress.

\begin{tabular}{|c|c|c|c|c|}
\hline Parameters & $\mathrm{C}$ & $\mathrm{I}$ & II & III \\
\hline Body weight (kg) & $556.62 \pm 21.18$ & $573.12 \pm 14.37$ & $579.38 \pm 9.53$ & $576.50 \pm 10.60$ \\
\hline Feed intake (kg/day) & $22.76 \pm 0.21^{\mathrm{b}}$ & $22.91 \pm 0.21^{\mathrm{b}}$ & $23.36 \pm 0.11^{\mathrm{a}}$ & $23.33 \pm 0.13^{\mathrm{a}}$ \\
\hline Milk yield (kg/day) & $27.70 \pm 0.36^{\mathrm{bc}}$ & $27.52 \pm 0.42^{\mathrm{b}}$ & $29.16 \pm 0.28^{\mathrm{a}}$ & $28.87 \pm 0.29^{\mathrm{ac}}$ \\
\hline Milk lactose $(\%)$ & $5.01 \pm 0.02^{\mathrm{b}}$ & $5.11 \pm 0.02^{\mathrm{a}}$ & $5.16 \pm 0.01^{\mathrm{a}}$ & $5.08 \pm 0.02^{\mathrm{ab}}$ \\
\hline Milk fat $(\%)$ & $3.44 \pm 0.07$ & $3.39 \pm 0.05$ & $3.37 \pm 0.07$ & $3.39 \pm 0.05$ \\
\hline Milk protein $(\%)$ & $2.99 \pm 0.05^{\mathrm{b}}$ & $3.06 \pm 0.04^{\mathrm{ab}}$ & $3.12 \pm 0.03^{\mathrm{a}}$ & $3.08 \pm 0.03^{\mathrm{a}}$ \\
\hline $\mathrm{T}-\mathrm{AOC}(\mathrm{U} / \mathrm{L})$ & $1.04 \pm 0.47^{\mathrm{b}}$ & $1.25 \pm 0.65^{\mathrm{b}}$ & $2.35 \pm 1.37^{\mathrm{a}}$ & $2.41 \pm 1.38^{\mathrm{a}}$ \\
\hline GSH-Px (U/L) & $115.73 \pm 17.04^{\mathrm{a}}$ & $116.23 \pm 8.36^{\mathrm{ab}}$ & $154.18 \pm 9.41^{\mathrm{a}}$ & $93.74 \pm 6.05^{\mathrm{b}}$ \\
\hline $\operatorname{MDA}(\mathrm{nM})$ & $1.25 \pm 0.42^{\mathrm{b}}$ & $1.50 \pm 0.20^{\mathrm{b}}$ & $2.09 \pm 0.74^{\mathrm{ab}}$ & $2.49 \pm 0.93^{\mathrm{a}}$ \\
\hline SOD $(\mathrm{U} / \mathrm{L})$ & $13.07 \pm 0.13^{\mathrm{ab}}$ & $13.31 \pm 4.40^{\mathrm{b}}$ & $14.78 \pm 2.87^{\mathrm{a}}$ & $22.17 \pm 1.41^{\mathrm{ab}}$ \\
\hline CPK (U/L) & $161.25 \pm 12.63^{b}$ & $131.83 \pm 14.24^{b}$ & $144.00 \pm 9.91^{\mathrm{b}}$ & $174.40 \pm 7.22^{\mathrm{a}}$ \\
\hline $\mathrm{T}_{3}(\mathrm{ng} / \mathrm{mL})$ & $1.85 \pm 0.13$ & $1.94 \pm 0.13$ & $1.89 \pm 0.15$ & $1.82 \pm 0.16$ \\
\hline $\mathrm{T}_{4}^{3}(\mathrm{ng} / \mathrm{mL})$ & $79.18 \pm 5.60$ & $76.89 \pm 3.97$ & $75.15 \pm 4.02$ & $81.92 \pm 4.34$ \\
\hline CORT (ng/mL) & $4.98 \pm 0.43$ & $5.75 \pm 0.51$ & $5.63 \pm 0.39$ & $7.45 \pm 1.16$ \\
\hline $\operatorname{ALT}(\mathrm{U} / \mathrm{L})$ & $34.25 \pm 1.21$ & $33.00 \pm 1.92$ & $35.88 \pm 1.95$ & $38.50 \pm 3.25$ \\
\hline LDH (U/L) & $776.57 \pm 32.20$ & $785.86 \pm 33.02$ & $861.00 \pm 38.46$ & $891.86 \pm 44.45$ \\
\hline BUN (mg/dL) & $5.09 \pm 0.13$ & $4.54 \pm 0.20$ & $4.80 \pm 0.22$ & $4.48 \pm 0.24$ \\
\hline GLU (mM) & $2.68 \pm 0.08$ & $2.61 \pm 0.05$ & $2.76 \pm 0.05$ & $2.61 \pm 0.11$ \\
\hline $\mathrm{TC}(\mathrm{mM})$ & $5.90 \pm 0.30$ & $5.66 \pm 0.46$ & $6.01 \pm 0.35$ & $5.59 \pm 0.24$ \\
\hline TG (mM) & $0.12 \pm 0.01$ & $0.13 \pm 0.01$ & $0.13 \pm 0.01$ & $0.14 \pm 0.02$ \\
\hline HSP70 (ng/mL) & $1.66 \pm 0.10$ & $1.56 \pm 0.06$ & $1.42 \pm 0.04$ & $1.54 \pm 0.08$ \\
\hline
\end{tabular}
$\overline{\mathrm{C}}=$ control group $(0 \mathrm{~g} /$ day of betaine $)$; $=$ group I (10 g/day of betaine); II = group II (15 g/day of betaine); III = group III (20 g/day of betaine). In the same row, values with different letter superscripts mean significant difference $(\mathrm{P}<0.05)$, and with same letter superscripts mean no significant difference $(\mathrm{P}>0.05)$. T-AOC $=$ total antioxidant capacity; GSH-Px = glutamic oxaloacetic transaminase; $\mathrm{MDA}=$ malondialdehyde; $\mathrm{SOD}=$ superoxide dismutase activity; $\mathrm{CPK}=$ creatine phosphate kinase; $\mathrm{T} 3=$ triiodothyronine; $\mathrm{T} 4=$ tetraiodothyronine; $\mathrm{CORT}=$ cortisol; ALT $=$ alamine aminotransferase; $\mathrm{LDH}=$ lactate dehydrogenase; $\mathrm{BUN}=$ blood urea nitrogen; $\mathrm{GLU}=$ glucose; $\mathrm{TC}=$ total cholesterol; HSP70 = heat stress protein 70.
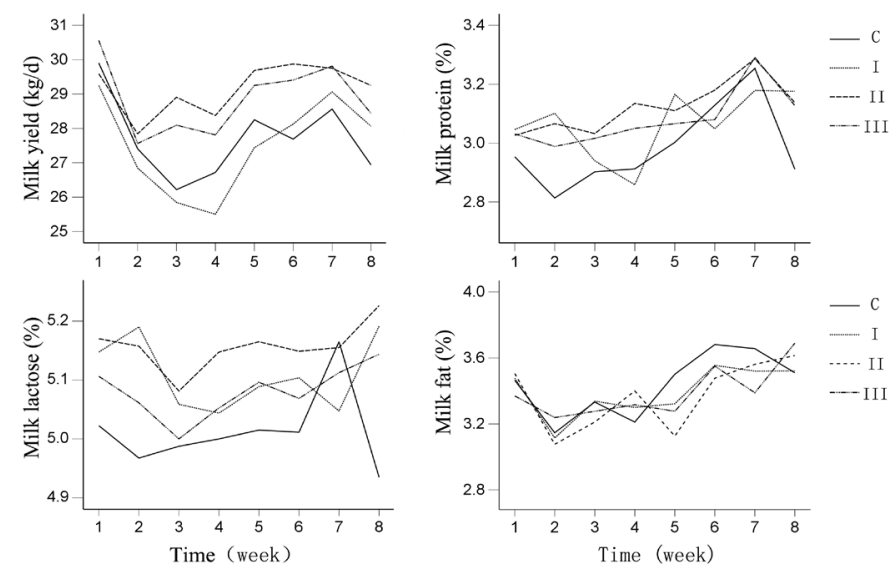

Figure 1. Lactation performance during dietary betaine supplementation in dairy cows under hot stress. $\mathrm{C}=$ the control group (no addition of betaine); $\mathrm{I}=$ group I (addition with $10 \mathrm{~g} /$ day betaine); II = group II (addition with 15 $\mathrm{g}$ /day betaine) ; III = group III (addition with $20 \mathrm{~g}$ /day betaine).

\section{Plasma antioxidant capacity}

The plasma antioxidant capacity is shown in Table 3 and Figure 2. Dietary betaine supplementation influenced plasma T-AOC, SOD, MDA, CRK, and GSH-Px activity $(\mathrm{P}<$ 0.05). GSH-Px activity was higher in the control group and group II compared to group III $(154.18$ vs. $93.74 \mathrm{U} / \mathrm{L} ; \mathrm{P}<0.05)$. MDA activity was higher in group III compared to the con- 
trol group and group I $(2.49 v s 1.25,1.50 \mathrm{nM})(\mathrm{P}<0.05)$. Superoxide dismutase activity was higher $(\mathrm{P}<0.05)$ in group II compared to group I. CPK activity was higher in group III $(\mathrm{P}<$ 0.05) compared to all other groups (174.40 vs $131.83 \mathrm{U} / \mathrm{L})$; however, CPK activity tended to decrease in groups C, I, and II.
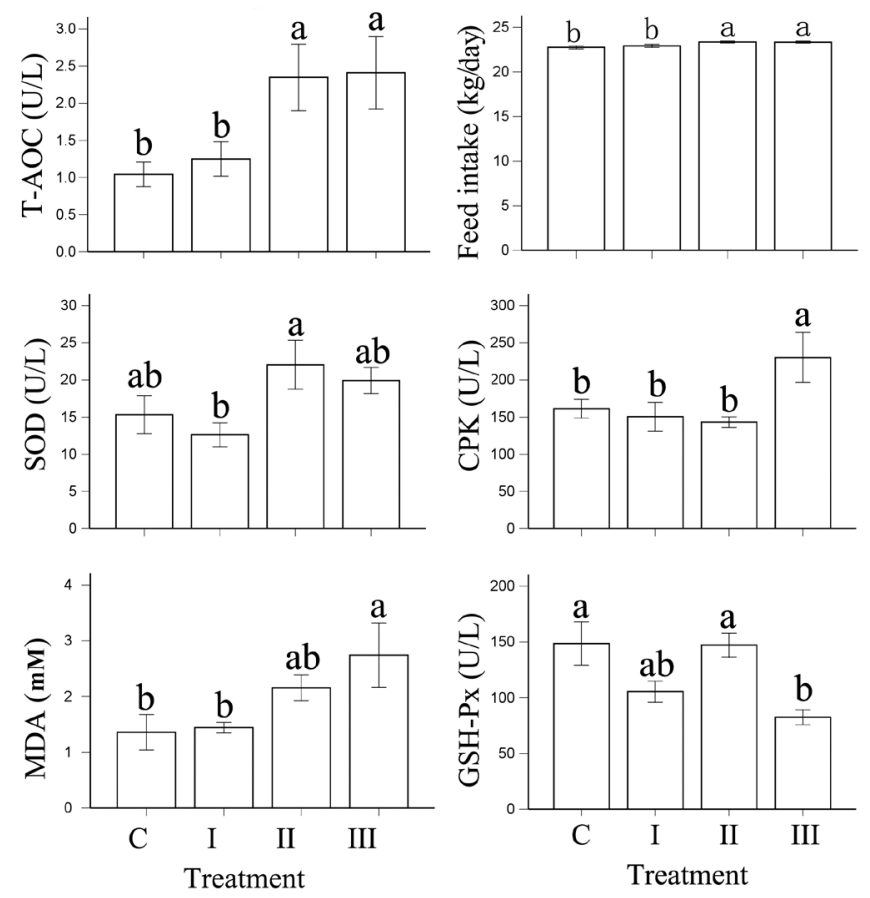

Figure 2. Feed intake and plasma antioxidant capacity in dairy cows following dietary betaine supplementation under hot stress. $\mathrm{C}=$ the control group (no addition of betaine); I = group I (addition with $10 \mathrm{~g} / \mathrm{d}$ betaine); II = group II (addition with $15 \mathrm{~g} / \mathrm{d}$ betaine); III = group III (addition with $20 \mathrm{~g} / \mathrm{d}$ betaine). Different small letters are significantly different from each other $(\mathrm{P}<0.05)$, the same letters or no letter are not significantly different from each other $(\mathrm{P}>0.05)$.

\section{Plasma metabolites and metabolic hormones}

The plasma metabolic hormones and metabolites from the 4 groups are shown in Table 3. There was no significant effect of treatment on plasma BUN, GLU, TC, TG, cortisol, $\mathrm{T}_{3}, \mathrm{~T}_{4}$, plasma ALT, or plasma LDH levels $(\mathrm{P}>0.05)$. Plasma HSP70 levels tended to decrease in groups $\mathrm{C}, \mathrm{I}$, and II; however, there was no significant difference among groups $(\mathrm{P}>0.05)$.

\section{DISCUSSION}

The cows suffered from heat stress when the THI was higher than 72 units. The feed intake and milk yield of cows decreased as THI increased (Armstrong, 1994; West, 2003). Rectal temperature is an important physiological indicator used to determine whether cows are 
being subject to heat stress, and ranges from $37.5^{\circ}$ to $39.1^{\circ} \mathrm{C}$ under normal physiological conditions. When cows are subjected to hot environmental temperatures, they cannot emit more heat by regulating body temperature, resulting in an increase in rectal temperature. Gaughan et al. (2005) suggested that the addition of exogenous permeates significantly reduces the rectal temperature, and increases the feed intake and heat endurance of cows during summer heat stress. The results of our study showed that the rectal temperature declined with increasing doses of betaine. This trend might be related to the function of betaine, which helps animals to alleviate heat stress.

Heat stress may cause a decline in milk yield, or changes to milk composition (Ravagnolo et al., 2000). In particular, the milk yield of high producing dairy cows may exhibit a sharp decrease (Wang C et al., 2010; Zimbelman et al., 2010). This phenomenon might be explained by several factors. First, heat stress causes a decline in feed intake, along with a decline in the digestion and absorption of nutrients, by dairy cows, reducing the flow of nutrients to the udder. About $50 \%$ of milk yield decrease is caused by a decline in feed intake by dairy cows (O'Brien et al., 2008). Heat stress also leads to metabolism disorders in dairy cows. To reduce the thermal burden in cows, the hypothalamus regulates the secretion of endocrine hormones. The hypothalamus reduces the secretion of $\mathrm{T}_{3}$ and $\mathrm{T}_{4}$, which inhibit the appetite and energy metabolism of cows. In parallel, the hypothalamus decreases the secretion of progesterone and prolactin, which reduce milk secretion, resulting in decreased milk production. Previous studies have reported that betaine might improve the milk yield of animals. For instance, it was found that adding 100 or $150 \mathrm{~g}$ of anhydrous betaine significantly improved milk yield during the early lactation of Holstein dairy cows (Wang J et al., 2010). During a 5 month trial, betaine also increased the milk yield of goats by 0.21 and $0.28 \mathrm{~kg} / \mathrm{day}(\mathrm{P}<0.05$; Sánchez et al., 2001; Fernández et al., 2004). In the current study, the addition of up to 15 and $20 \mathrm{~g} /$ day betaine caused milk yield to increase by 29.16 and $28.87 \mathrm{vs} .27 .70 \mathrm{~kg} /$ day (control), respectively. This increase might have been caused by the addition of 15 and $20 \mathrm{~g} /$ day of betaine reducing the heat stress of cows, which, in turn, increased feed intake, and milk yield. Heat stress also leads to changes in milk quality, mainly by reducing milk lactose and milk protein levels (Ravagnolo et al., 2000). The results obtained in this study showed that betaine fed cows exhibited an increase in milk protein. For instance, the milk protein percentage of the group fed with $15 \mathrm{~g} /$ day betaine was $3.12 \%(\mathrm{P}<0.05)$, which was ranked the highest level of all groups. However, milk fat content was not influenced by the addition of betaine to feed.

Both the thyroid and adrenal gland are important for animals to regulate heat stress. $\mathrm{T}_{3}$ and $\mathrm{T}_{4}$ are the main substances secreted by the thyroid. $\mathrm{T}_{3}$ is mainly transformed from $\mathrm{T}_{4}$. Although lower quantities of $T_{3}$ are produced compared to $T_{4}$, its activity is stronger than $T_{4}$. $\mathrm{T}_{3}$ and $\mathrm{T}_{4}$ levels in serum decline when animals are subject to heat stress. This phenomenon occurs because lowered thyroid hormone levels reduce heat production, which helps the body to adapt to warmer environments (Horowitz, 2002). Lower secretions of $\mathrm{T}_{3}$ and $\mathrm{T}_{4}$ reduce milk secretion, resulting in a decline in milk yield (Johnson, 1988). In the current study, $\mathrm{T}_{3}$ and $\mathrm{T}_{4}$ levels in the blood decreased by varying degrees in betaine fed cows. CORT is a steroid hormone synthesized by adrenal cortex cells, which regulate the metabolism of glucose, protein, fat, water, and salt. This activity promotes protein and fat decomposition, which increases the reserves of glycogen in the animal's body. When animals are under stress, the cortisol content of the body immediately increases. During the current experiment, CORT increased in the betaine groups. This result indicates that cows are affected by the heat during summer. 
The results showed that the supplementation of $15 \mathrm{~g} /$ day of betaine was the most favorable quantity for stabilizing the endocrine hormone content of cows under the heat stress. This observation is explained by the fact that betaine lowers the basal metabolic rate. Similar studies previously reported that betaine reduces the maintenance requirement and metabolic heat production of growing pigs, and found that metabolic heat production decreased significantly over time (Schrama et al., 2003).

Heat stress may induce an increase in the formation of endogenous free radicals, and cause a reduction in the antioxidant capacity of animals. Such changes are reflected by the activity of antioxidant enzymes in the serum, including a significantly reduction in the activity of SOD and GSH-Px, and an increase in the activity of ROS and MDA. Previous studies found that the antioxidant capacity of betaine enabled it to scavenge free radicals and protect cells from loss in rats (Lu et al., 2008). In this study, the GSH-Px content in blood plasma improved in the group fed with $15 \mathrm{~g}$ /day betaine. In comparison, SOD content increased by adding $20 \mathrm{~g} /$ day betaine. These results indicate a reduction in the reactive oxygen species and free radicals, along with an improvement in the antioxidant capacity.

In summer, the energy supply (mainly contains maintain requirements and milk secretion) is generally insufficient for cows; consequently, the body is in a state of negative energy balance. The energy supply is mainly dependent on the oxidation of free fatty acids (O'Brien et al., 2008). The liver activity of cows declines during summer heat stress compared to cows inhabiting thermally optimal environments. In addition, the cholesterol and triglyceride levels in blood plasma also decline. These phenomena may be caused by an increase in the mobilization of fat in the peripheral tissue (Abeni et al., 2007). As a methyl donor, betaine has the role of promoting fatty acid oxidation (Davidson et al., 2008). Previous studies have shown that the addition of exogenous betaine reduces the triglyceride levels in the blood of goats (Fernandez et al., 2009). During summer heat stress, the muscle energy supply of an animal is insufficient, because the membrane phospholipid layer is oxidized, causing an increase in membrane permeability. This activity causes CPK overflow in the extracellular domain, resulting in a significant increase in CPK levels in the peripheral blood. The results of this study showed a decline in CPK when 10 and $15 \mathrm{~g} /$ day betaine were supplemented in the feed. This result indicates that the liver and muscle organs of cows were minimally damaged during the test. This outcome might be explained by the oxidation of fatty acid, which supplemented the need for energy by the body. The addition of $20 \mathrm{~g} /$ day of betaine led to an increase in CPK levels; however, further studies are required to validate this observation. Heat stress may cause the immune system of an animal to become suppressed, along with the suppression of blood urea nitrogen. These processes are mainly regulated by modification of the brain function on the immune system (Zhan, 2001). The brain transmits information to the immune organs via the pituitary-adrenal pathway when an animal is subject to thermal stimulation, activating the GH (growth hormone) involved in regulating immunity. The results of the current study showed that betaine might reduce urea nitrogen levels, thus improving the retention of plasma total nitrogen. These actions are beneficial to the immunity and nitrogen accumulation of cows.

In the current experiment, lactating dairy cows were exposed to heat stress, and supplemented with different doses of betaine. We found that betaine supplementation enhanced milk yield and milk components. Betaine supplementation exhibited minor effects on rectal temperature, respiration rate, and pulse rate of dairy cows. In addition, betaine supplementation improved the antioxidant capacity of cows, but did not influence their physiological status. 


\title{
ACKNOWLEDGMENTS
}

\author{
Research supported by the National Supporting Projects for Science and Techniques \\ (\#2012BAD12B00).
}

\section{REFERENCES}

Abeni F, Calamari L and Stefanini L (2007). Metabolic conditions of lactating Friesian cows during the hot season in the Po valley. 1. Blood indicators of heat stress. Int. J. Biometeorol. 52: 87-96.

Al-Saiady M, Al-Shaikh MA, Al-Mufarrej SI, Al-Showeimi TA, et al. (2004). Effect of chelated chromium supplementation on lactation performance and blood parameters of Holstein cows under heat stress. Anim. Feed Sci. Tech. 117: 223233.

Armstrong DV (1994). Heat stress interaction with shade and cooling. J. Dairy Sci. 77: 2044-2050.

Davidson S, Hopkins BA, Odle J, Brownie C, et al. (2008). Supplementing limited methionine diets with rumen-protected methionine, betaine, and choline in early lactation Holstein cows. J. Dairy Sci. 91: 1552-1559.

Fernández C, Sánchez-Seiquer P SA, Contreras A and de la Fuente JM (2004). Influence of betaine on milk yield and composition in primiparous lactating dairy goats. Small Ruminant Res. 52: 37-43.

Fernández CJ, Mata-anguiano CM, Piquer-Querol O, Bacha-Baz F, et al. (2009). Influence of betaine on goat milk yield and blood metabolites. Trop. Subtrop. Agroecosystems 11: 209-213.

Gaughan J, Cadogan D, Cawdell-Smith A, Roft I, et al. (2005). Improved heat tolerance of cattle by dietary supplementation with osmolytes. Asia Pac. J. Clin. Nutr. 14: S123.

Horowitz M (2002). From molecular and cellular to integrative heat defense during exposure to chronic heat. Comp. Biochem. Physiol. A Mol. Integr. Physiol. 131: 475-483.

Huber JT, Higginbotham G, Gomez-Alarcon RA, Taylor RB, et al. (1994). Heat stress interactions with protein, supplemental fat, and fungal cultures. J. Dairy Sci. 77: 2080-2090.

Johnson H (1988). Environmental physiology and shelter engineering with special reference to domestic animals. LXXVI: short-term heat acclimation effects on hormonal profile of lactating cows, Part II. University of Missouri-Columbia, College of Agriculture, Agricultural Experiment Station, Columbia.

Lu X, Wang J, Wang H, Qu S, et al. (2008). Effects of betaine on body weight and biochemical index in obese rats fed high-fat diet. Acta Nutrimenta Sinica 3: 023.

Maust L, McDowell RE and Hooven NW (1972). Effect of summer weather on performance of Holstein cows in three stages of lactation. J. Dairy Sci. 55(8): 1133-1139.

NRC (2001). Nutrient requirements of dairy cattle. 7th edn. National Academy Press, Washington DC.

O'Brien M, Wheelock JB, Baumgard LH, Rhoads ML, et al (2008). The effects of heat stress on production, metabolism and energetics of lactating and growing cattle. Florida Ruminant Nutrition Symposium, Gainesville.

Ravagnolo O and Misztal I (2000). Genetic component of heat stress in dairy cattle, parameter estimation. J. Dairy Sci. 83: 2126-2130.

Sánchez P, Muelas R, Sánchez A, Rubert J, et al. (2001). Influence of betaine on somatic cell count and goat milk composition. Book of Abstracts of the 52nd Annual Meeting of European Association for Animal Production, Budapest.

Schrama JW, Heetkamp MJ, Simmins PH and Gerrits WJ (2003). Dietary betaine supplementation affects energy metabolism of pigs. J. Anim. Sci. 81: 1202-1209.

Wang C, Liu Q, Yang WZ, Wu J, et al. (2010). Effects of betaine supplementation on rumen fermentation, lactation performance, feed digestibilities and plasma characteristics in dairy cows. J. Agr. Sci. 148: 487-495.

Wang J, Guo T and Li F (2010). Research on performance and ruminal fermentation of high and mid lactating dairy cows in hot weather. Chin. J. Anim. Nutr. 1: 014.

West JW (2003). Effects of heat-stress on production in dairy cattle. J. Dairy Sci. 86: 2131-2144.

West JW, Mullinix BG and Bernard JK (2003). Effects of hot, humid weather on milk temperature, dry matter intake, and milk yield of lactating dairy cows. J. Dairy Sci. 86: 232-242.

Zhan X (2001). Effects of betaine on immune responses of newcastle disease in broiler chicks. C. J. Vet. Sci. 21: 100-102.

Zimbelman RB, Baumgard LH and Collier RJ (2010). Effects of encapsulated niacin on evaporative heat loss and body temperature in moderately heat-stressed lactating Holstein cows. J. Dairy Sci. 93: 2387-2394. 